\title{
The Unnoble Nobles: Notes on Shakespeare's Masterful Characterization in Macbeth
}

\author{
Zohreh Ramin ${ }^{1}$, Alireza Shafinasab ${ }^{2}$ \\ ${ }^{1}$ Assistant Professor of English Language and Literature, Department of English, Faculty of \\ Foreign Languages and Literatures, University of Tehran, Tehran, Iran \\ ${ }^{2}$ MA Student of English Language and Literature, Department of English, Faculty of Foreign \\ Languages and Literatures, University of Tehran, Tehran, Iran \\ E-mail address: zramin@ut.ac.ir
}

Keywords: Macbeth; Holinshed's Chronicles; Banquo; murderer; noble

\begin{abstract}
When writing Macbeth, Shakespeare faced a moral and aesthetic challenge. On the one hand, he had drawn the story of Macbeth from Holinshed's Chronicles, in which Banquo is depicted as an accomplice in the murder of King Duncan. On the other hand Banquo was believed to be the ancestor of King James, Shakespeare's patron. Shakespeare had to write a play that at once pleased King James, remained true to the spirit of history, and could be a popular hit in the commercial world of Jacobean theatre, all seemingly contradictory ends because of the problem with the character of Banquo. So Shakespeare characterizes him in a different manner from his sources. The new characterization served a number of purposes. The most important reason for the alternation was to please King James, the alleged descendant of Banquo. Other than that, there is the dramatic purpose of creating a foil character for Macbeth, who can highlight Macbeth's characteristics. The presence of a noble Banquo also shows that human being can resist evil, as does Banquo. These points have been emphasized in many writings on Macbeth, which mean that Shakespeare's Banquo is an innocent man, a seemingly deviation from history. The present paper, however, tries to examine Shakespeare's complex characterization of Banquo which must meet those seemingly contradicting ends, a characterization far more ambivalent and artful than simple political affiliations might suggest. It will be shown that Shakespeare's Banquo not only is not simply an innocent man he seems to be at the first reading, but he could be as murderous as Macbeth himself. The only difference between the two is that one acts sooner than the other.
\end{abstract}

\section{INTRODUCTION}

A traditional reading of Macbeth by William Shakespeare shows Macbeth and his lady as the villains, and Banquo as a pure innocent victim of Macbeth's ambition, who is unaware of Macbeth's plot to kill the king. Shakespeare's source for this play was Holinshed's Chronicles (Law, 1952), which relates, among many others, the historical account of Macbeth. Holinshed's Banquo, however, is quite different from Shakespeare's version of the character. In the Chronicles, Banquo is an accomplice in the murder of King Duncan. But in Shakespeare's version of the story he seems to be a noble man till the end. When writing Macbeth, Shakespeare faced a difficult aesthetic and moral challenge. He had to produce a text that at once pleased King James, for Banquo was believed to be the ancestor of the king, remained true to the history, as written in Holinshed and could be a popular hit in the highly competitive commercial theatrical world of Jacobean London. His solution was to make Banquo into a more complex figure than he is in his sources. The present study tries to examine the complex characterization of Banquo and to show how Shakespeare manages to meet these seemingly contradictory aims. It will be shown that Banquo's character is not as innocent as he seems. The argument will be based on the pattern of action and thought that is found in the play. Both Macbeth and Banquo have the same thoughts and the same actions, but Banquo is a bit belated at the end. Both at first are noble soldiers for their king, then they meet the 
witches. Both are curious about what the witches have to tell them. Both at first deny the prophecies, then believe them. Both at first want to leave everything to fate, but when they are disappointed they decide to take action and make them come true. Both have plans for killing their way to the throne, and feel guilty because of this. Each of them is suspicious of the other and because of this, tries to kill that other. In some of these steps it is Macbeth who is behind, for example he comes to believe in the prophecies way after Banquo, but in the last step, the most crucial one, Macbeth acts quicker and remains on the throne (the events after that are not related to this argument). In this paper, first the reasons Shakespeare tried to transform Banquo into a righteous soldier will be discussed, then, in the second part, the pattern mentioned above will be elaborated on and it will be examined how different the character of Banquo can be from what he seems to be.

\section{BANQUO AS THE NOBLE MAN}

Shakespeare tries to show a Banquo who, unlike the assassin in the Chronicles, is a noble soldier. Banquo, in the beginning of both works is actually a noble soldier who fights for his king. The king in Macbeth addresses Banquo and Macbeth similarly: "O worthiest cousin!" for Macbeth and "worthy" and "noble Banquo". But in Holinshed's account Banquo soon becomes Macbeth's accomplice in the murder of King Duncan:

At length therefore, communicating his purposed intent with his trustie friends, amongst whome Banquo was the chiefest, upon confidence of their promised aid, he slue the King ... (Holinshed, 1965).

A number of researches have been done as to why Shakespeare makes such alternations to Banquo. The different characterization of Banquo in Shakespeare's Macbeth serves a number of purposes. The most important reason for such alternations is King James. He was Shakespeare's patron and this play was performed to please the king (Williams, 1982). At that time, it was believed that King James was Banquo's descendant ${ }^{1}$ (Muir, 1962), and this presumption has certainly influenced Shakespeare's characterization of Banquo as a noble character who is an innocent victim rather than an assassin (at least, apparently). Of course Shakespeare, who usually changes his sources to make the stories more dramatic, can easily alter his king's ancestor from a murderer to an apparently noble man. Depicting the historical Banquo, James' ancestor, as he was, might have ruined Shakespeare's career, and because of this reason other writers of that time, like Jean de Schelandre, also transformed Banquo into a noble man (Maskell, 1971). There are a number of other changes that Shakespeare makes into historical Macbeth in order to please King James which are out of the scope of this study (refer to Macbeth: Language and Writing (2013) by Emma Smith for the full extent of such transformations).

However Macbeth has to combine royal flattery with popular drama. It is theatrically more interesting to have a foil character, rather than another accomplice in this play. A foil character is defined as "A character in a work who, by sharp contrast, serves to stress and highlight the distinctive temperament of the protagonist is termed a foil." (Abrams, 1993) In this view, Shakespeare's Banquo is the exact foil and dramatic contrast to Macbeth (Nagarajan, 1956) and Banquo's murder is turned into a loathsome act. Killing an accomplice would not provoke such sympathetic responses from the audience.

Since Shakespeare shows the struggle between fate and freewill in Macbeth, having a wise and reasonable character in crucial moments is essential to the thematic issues of evil and the effects it has on men. Banquo, who is intended to be such a character, warns Macbeth:

That trusted home

Might yet enkindle you unto the crown,

Besides the thane of Cawdor. But 'tis strange:

And oftentimes, to win us to our harm,

The instruments of darkness tell us truths,

Win us with honest trifles, to betray's

In deepest consequence. (1.3. 120-6) 
Banquo's ability to resist the forces of evil "points up Macbeth's failure to resist, and stresses his tendency towards evil, the flaw that makes the tragedy possible" (Boyce, 1990). As Mehl (1986) puts it "Shakespeare lays great stress on the different reactions of Banquo and Macbeth and this alone should make perfectly clear that the 'weird sisters' power over human will is very limited; they can suggest, not direct". This aspect of Banquo's character has been most emphasized by critics throughout time. For example $19^{\text {th }}$ century Shakespearean actor and critic, Fanny Kemble, while calling the play "the most wonderful history of temptation, in its various agency upon the human soul", emphasizes the "moral power which Shakespeare has placed beside it in the character of Banquo! ... the clear integrity of Banquo's soul remains unsullied by the serpent's breath (Kemble, 1882) Many other such instances are found in the writings on Macbeth, all emphasizing the pure soul of Banquo, which is not tempted. All such notes point to Macbeth's yielding to evil.

\section{WHO IS THE MURDERER?}

The two names, Macbeth and Banquo, appear a number of times together, implying their equality in the beginning. From the third scene of the play, we meet them in an equal situation. Both have fought the battle bravely, and now on their way back, they meet the witches. So what does happen that Banquo remains the "noble Banquo" and Macbeth becomes "the tyrant"? Why on earth are they called noble in the beginning? The reason for their nobleness is that they have killed. They kill for the king. All their nobleness lies in their violence and killing others. In fact, when Shakespeare wants to give us a glorious first impression of Macbeth, unlike the Macbeth of the Chronicles who finds Macdonwald dead, he puts into the mouth of the Sergeant the report how Macbeth could kill "The merciless Macdonwald", "the slave" and fix "his head upon our battlements". This way the audience will know how noble Macbeth is. But when the battle is over, Macbeth continues killing, but this time not for the king, but for his own ambition. When the murders are to his own interest, not those of the king, he is called the murderer, not the noble man he used to be. But Banquo, who has killed as much as Macbeth has, kills nobody after the battle, though, as will be shown he plans to, and his killings remain limited to those that were for the service of the king, so he remains the "noble Banquo". But there is something more to what Macbeth and Banquo do, something that might not be noticeable in the first reading of the play.

From the scene when Macbeth and Banquo meet the witches, Banquo seems to be as eager about the prophecies as Macbeth is. He not only considers what the witches tell Macbeth as "fair", but also he is, maybe out of jealousy to what is promised to Macbeth, highly interested to know what the witches have in store for him:

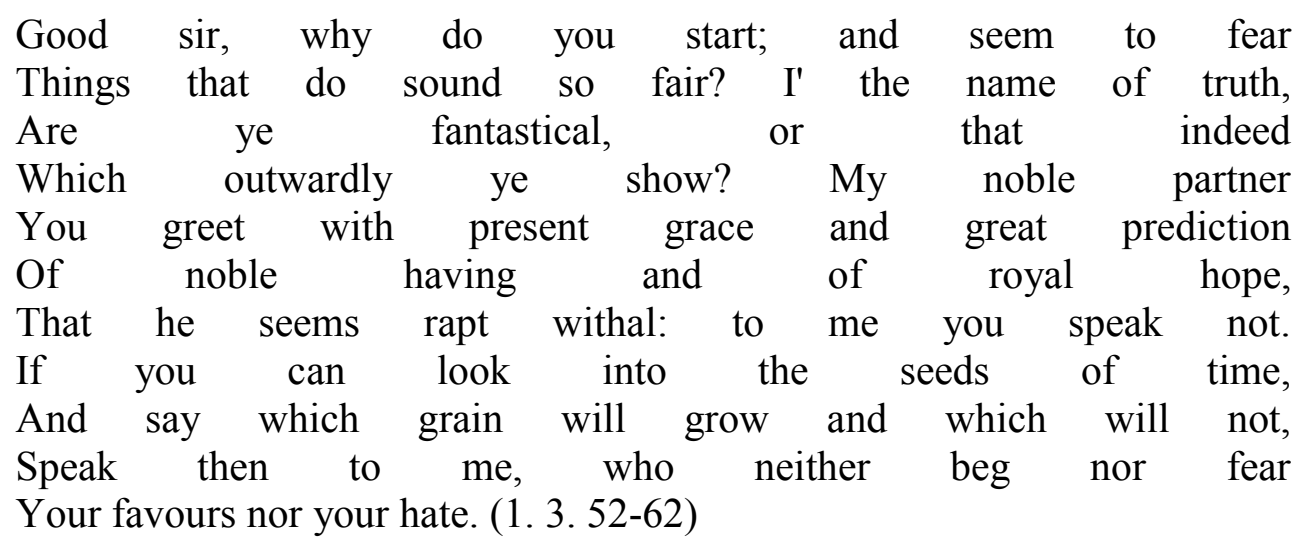


His eagerness to know about witches' prophecies is equal to that of Macbeth who tells the witches: "Stay, you imperfect speakers, tell me more:". In fact, Banquo has been so charmed by the prophecy that his descendants will be kings that he thinks he has seen a fantasy:

Were such things here as we do speak about?
Or have

That takes the reason prisoner? (1.3.84-6)

When Ross informs Macbeth that King Duncan has appointed him as the thane of Cawdor, Banquo is the first to remember the witches again: "What, can the devil speak true?" (1. 3. 107) indicating that he has been thinking deeply, maybe more than Macbeth does, about them. In fact, his reaction shows that Banquo, unlike Macbeth, has completely believed what the witches have prophesied. Macbeth at first tries to deny this fact and questions about his appointment as the thane of Cawdor, trying not to believe it: "The Thane of Cawdor lives. Why do you dress me / In borrowed robes?" (1. 3. 108-9). But Banquo's response shows that he has believed everything he and Macbeth have been told. Later when they are invited by the King, Banquo answers Macbeth, when asked to think about what they saw and to talk about it later, that he would "very gladly" do so.

Banquo appears to be sleepless, and tormented by guilty conscience even before Macbeth. In the first scene of Act II, Banquo says to his son, Fleance:

Hold, take my sword. There's husbandry in heaven;
Their candles are all out. Take thee that too.
A heavy summons lies like lead upon me,
And yet I would not sleep: merciful powers,
Restrain in me the cursed thoughts that nature
Gives way to in repose! (2.1.4-9)

There are a number of hints in this short passage that show that Banquo too has nourished murderous thoughts after meeting the witches and hearing their prophecy. First of all, he gives his sword as well as his dagger (Take thee that too) (Westbrook, 1946) to his son, lest he be tempted to go and murder the King while he is sleeping. Of course, he does not like such thoughts and wants to get rid of them, as we shall see later, by any way possible, but they are tormenting him. He also remarks that he cannot sleep, which is the result of the murderous thoughts mentioned earlier. The fact that Banquo has nourished such thoughts on his mind is also suggested by the line "restrain in me the cursèd thoughts ..." (2. 1.8).

At that same scene, when he sees Macbeth, he is amazed that Macbeth is not asleep yet and mentions that the King is asleep. He seems to be expecting Macbeth, as well as the King, sleeping. He tells Macbeth that he has dreamt about the weird sisters, and he is eager to talk to Macbeth about them:

I dreamt last night of the three weird sisters:

To you they have show'd some truth. (2.1. 18-9)

The first scene of Act III, when Macbeth has already killed King Duncan, begins with Banquo's soliloquy:

Thou hast it now: king, Cawdor, Glamis, all, As the weird women promised, and, I fear,

Thou play'dst most foully for't: yet it was said

It should not stand in thy posterity,

But that myself should be the root and father

Of many kings. If there come truth from them--

As upon thee, Macbeth, their speeches shine--

Why, by the verities on thee made good,

May they not be my oracles as well,

And set me up in hope? But hush! no more. (3. 1. 1-10) 
In this passage, he tries to project on Macbeth the thoughts he has been nourishing in his mind about murdering Duncan, though all the evidence Macbeth has been fabricating shows otherwise. In fact, suspecting Macbeth leads him to a correct conclusion, that Macbeth, and not the guards, has murdered King Duncan. As mentioned earlier, the scene in which he gives his sword and dagger to Fleance clearly shows what he has in mind. The very Shakespeare who wrote Macbeth, notes in King Henry VI, part III, that "Suspicion always haunts the guilty mind;" (Shakespeare, p144). He is suspicious of Macbeth because he has already thought about killing the king and feels guilty for such thoughts. But now that the burden has been removed, i.e. King Duncan has been killed by someone else, he is relieved and most directly tells us of the hope that he has for the prophecies to come true, that the monarchy "should not stand in thy posterity / But that myself should be the root and father / Of many kings." It seems that "the anxiety he had earlier about the instruments of darkness seems now to have disappeared" (Rosenberg, 1978). This passage is also similar to Macbeth's soliloquy in the third scene of act I where, before actually deciding to murder King Duncan, he contemplates: "If chance will have me king, why, chance may crown me / Without my stir". This implies that Banquo is undergoing the same thinking process as Macbeth, but he is just one step behind.

Other than the soliloquies, Banquo's hope of getting the throne from Macbeth is suggested by the fact that upon hearing the death of Duncan, he shouts, somewhat hypocritically, that:

In the great hand of God I stand, and thence

Against the undivulged pretence I fight

Of treasonous malice. (2.3.131-3)

But this is all we see of him, and after guessing that it is Macbeth who has killed King Duncan, he remains silent and lets nobody know about it, because doing so there would practically be no opportunity for Banquo to seize the throne. As A. C. Bradley (1905) remarks "He is profoundly shocked, full of indignation, and determined to play the part of a brave and honest man. But he plays no such part. When next we see him, on the last day of his life, we find that he has yielded to evil. The Witches and his own ambition have conquered him". Of course Bradley believes that Banquo is initially a noble character, but the events of the play make him yield to evil.

Banquo is suspicious of Macbeth because he feels guilty, but this time not because of the thoughts about murdering King Duncan, but about murdering Macbeth himself. This would be the step that would completely fulfill the prophecies. In the fourth scene of Act I, when Macbeth hears that the king assigns his son, Malcolm, as the Prince of Cumberland, he soon leaves there, with the excuse of informing his wife that the king is going to be their guest, but in fact he wants to plan how he can murder Duncan. The same happens to Banquo in the Act III. Upon the coronation of Macbeth, Banquo, who sees that there is no other way his son can be king except by removing Macbeth, leaves there, claiming that it is only for a ride, but there are some other reasons for his leaving. Firstly, since he thinks of killing Macbeth, he also suspects that Macbeth wants to kill him, or, more importantly, his son, who is promised to be the king in the future. So, this ride is to protect his son. The same thought passes through Macbeth's mind too. Since Macbeth is afraid that Banquo might kill him and crown his own son, he decides to kill Banquo. For Banquo, maybe protecting his son is not the only reason for such a ride; he also wants to have some free time to think about how he can murder Macbeth, and fulfill the prophecies. This again reminds of what Macbeth had done, when he took his leave from the king and rode to his castle. But while Banquo is out with his son, Macbeth sends a number of murderers to kill him. Banquo might, given enough time, show his real self and do the same thing to Macbeth that Macbeth did to King Duncan. In other words, Banquo did not get the opportunity to realize his plans, because his life was short. And the only difference between he and Macbeth was that Macbeth acted what was in his mind sooner than Banquo, and did not leave Banquo the opportunity to do the same to him. Perhaps, if Banquo acted sooner than Macbeth, Macbeth would be the innocent man we see in Banquo, not the murderer that he is usually 
viewed as. What makes all the difference between the hated murderer and the noble innocent man is a matter of time.

\section{CONCLUSION}

We saw that, unlike the traditional readings of the play, Banquo and Macbeth are similar in many respects. Banquo undergoes the same pattern of thinking and action as Macbeth; he is only one step behind. Shakespeare is so confident in his talent that he does not allow himself to alter a character simply from evil to noble without any complex characterization because of someone else, that is, King James, so he deliberately leaves these clues, so that a close reading, or watching, reveals the complex characterization. What such a reading reveals is that Banquo is not the nobleman he is usually viewed to be. Macbeth is a play about equivocation, equivocation in loyalty, equivocation in self-interest. In such a morally and physically dangerous world it is not surprising that there are 'Nobles' but not noble men, and Banquo becomes a figure as ambivalent as the rest of the cast.

1 The audience of Shakespeare's time supposed that their King, James I, was a descendant of Fleance, Banquo's son. It should be noted, however, there is no historical evidence for that and David Dalrymple calls histories that claim such a thing "fabulous genealogies" (French, 2009)

\section{References}

[1] Abrams, M. H. 1993. A glossary of literary terms. 6th ed. Fort Worth: Harcourt Brace Jovanovich College Publishers.

[2] Boyce, Charles. 1990. Shakespeare A to Z: the essential reference to his plays, his poems, his life and times, and more. New York: Facts on File.

[3] Bradley, A. C. 1905. Shakespearean tragedy; lectures on Hamlet, Othello, King Lear, Macbeth,.2d ed. London: Macmillan and Co.

[4] French, George Russel. 1905. The Ancestry of Her Majesty Queen Victoria, and of His Royal Highness Prince Albert. New York: Frederiksen Press.

[5] Holinshed, Raphael. 1965. Holinshed's Chronicles: England, Scotland, and Ireland : London:- 1807-08 : 6 vol.. New York: AMS Press.

[6] Kemble, Fanny. 1965. Notes Upon Some of Shakespeare's Plays. Whitefish: Kessinger Publishing.

[7] Law, Robert Adgar. 1952. The Composition of "Macbeth" with Reference to Holinshed. The University of Texas Studies in English 31: 35-41

[8] Maskell, D. W. 1971. The Transformation of History into Epic: The 'Stuartide' (1611) of Jean de Schelandre. The Modern Language Review 66(1): 53-65.

[9] Mehl, Dieter. 1986 Shakespeare's tragedies: an introduction. Cambridge: Cambridge University Press.

[10] Muir, Kenneth, and William Shakespeare. 1962 Macbeth. 9th ed. London: Methuen.

[11] Nagarajan, S. 1956. A Note on Banquo. Shakespeare Quarterly 7(4): 371-376.

[12] Rosenberg, Marvin. 1978. The Masks of Macbeth. Berkeley: University of California Press.

[13] Shakespeare, William. 2005. Macbeth, The Annotated Shakespeare. New Haven and London: Yale University Press.. 
[14] Shakespeare, William. 2005 King Henry VI, Part III: Webster's Thesaurus Edition. San Diego ICON Group International, Inc,

[15] Smith, Emma. 2013. Macbeth: language and writing. London: Bloomsbury Arden Shakespeare.

[16] Westbrook, Perry D. 1946. A Note on "Macbeth," Act II, Scene 1. College English 7(4): 219220.

[17] Williams, George Walton. 1982. "Macbeth": King James's Play. South Atlantic Review 47(2): 12-21. 